\title{
The effect of Helicobacter pylori on the gastric expression of LOX-1 and CD-36: the role of CRP and ox-LDL
}

\section{Gholamreza Ghanbariha}

Semnan University of Medical Sciences and Health Services

\section{Reza Dabiri}

Semnan University of Medical Sciences and Health Services

\section{Majid MirmohammadKhani}

Semnan University of Medical Sciences and Health Services

\section{Mojdeh Habibzadeh}

Semnan University of Medical Sciences and Health Services

\section{Vahid Semnani}

Semnan University of Medical Sciences and Health Services

Abbas Pakdel ( $\nabla$ pakdel@semums.ac.ir)

Semnan University of Medical Sciences and Health Services https://orcid.org/0000-0002-7173-367X

\section{Research Article}

Keywords: LOX-1, CD-36, hs-CRP, ox-LDL, Gastritis

Posted Date: February 10th, 2022

DOI: https://doi.org/10.21203/rs.3.rs-1324278/v1

License: (9) (i) This work is licensed under a Creative Commons Attribution 4.0 International License. Read Full License 


\section{Abstract}

Background: This study aimed to investigate the effect of serum C-reactive protein (CRP) and oxidized low-density lipoprotein (ox-LDL) concentrations on the expression of lectin-like oxidized low-density lipoprotein (LOX-1) and cluster of differentiation $36(C D-36)$ genes in gastric biopsies of individuals with and without Helicobacter pylori (H. pylori) infection.

Methods and Results: In this cross-sectional study, we investigated 74 subjects based on gastritis and $\mathrm{H}$. pylori infection in three groups. Enzyme-linked immunosorbent assay (ELISA) was used to measure serum levels of high-sensitivity CRP (hs-CRP) and ox-LDL. Quantitative real-time RT-PCR was run to compare LOX-1 and CD-36 gene expression.

Comparison of LOX-1 gene expression in $H$. pylori and gastritis positive $(\mathrm{P}=0.025)$ and $H$. pylori-negative and gastritis-positive $(\mathrm{P}=0.010)$ to $H$. pylori and gastritis-negative groups showed a significant difference. $C D-36$ expression levels were lower in the H. pylori and gastritis positive group than in the nongastritis and $H$. pylori group $(\mathrm{p}=0.051)$. Although there was a weak correlation between serum hs-CRP concentration and $L O X-1$ expression $(r=0.219, P=0.058)$, there was no correlation between serum levels of ox-LDL and $L O X-1$ expression and $C D-36$.

Conclusion: Based on the investigation results, two factors, H. pylori, and gastritis increase LOX-1 expression and decrease $C D-36$ expression. Based on our results, an increase in plasma hs-CRP levels may be associated with an increase in $L O X-1$ expression.

\section{Introduction}

Helicobacter pylori (H. pylori) is a gram-negative, spiral, microaerophilic, and flagellate bacterium localized in the human stomach. Approximately half of the world's population is infected with this bacterium. H. pylori can colonize gastric tissue and attach it to epithelial cells with its flagella and adhesion molecules. By releasing toxins, it can cause tissue damage and inflammation [1]. Chronic gastritis is usually an asymptomatic disease that is highly important, since it causes stomach cancer in some patients. There are two types of gastritis. In most cases, gastritis is caused by H. pylori infection. The autoimmune type of gastritis is scarce [2].

Lectin-like oxidized low-density lipoprotein receptor-1 (LOX-1) is a type II membrane protein that structurally belongs to the type $C$ lectin family [3]. In addition to being an oxidized low-density lipoprotein (ox-LDL) receptor, this protein can bind to C-reactive protein (CRP) in endothelial cells with a lower affinity than that of ox-LDL. Despite its lower CRP affinity for binding to this receptor, it induces LOX-1 expression and can play a role in carcinogenesis [4-6, 3,7-9]. H. pylori-induced acute and chronic gastritis can cause many changes in gene expression. It may lead to gastric cancer. Elevated serum levels before CRP treatment $(>10 \mathrm{mg} / \mathrm{L}$ ) are significantly associated with poor prognosis in patients with gastric cancer, both in early and advanced stages $[10,11]$. Activation of $L O X-1$ causes the transformation and growth of several cancer cells, while decreased LOX-1 expression can prevent such processes [12]. Some studies 
have demonstrated that overexpression of $L O X-1$ is involved in tumor progression in prostate, colorectal, gastric, pancreatic, and breast cancers $[13,6,5,4,14]$.

Cluster of differentiation $36(C D-36)$ is an $88 \mathrm{kDa}$ membrane glycoprotein belonging to the scavenger receptor $\mathrm{B}$ family. $C D-36$ is present on the surface of several cells, such as fat cells, monocytes, macrophages, platelets, endothelial, cardiac, skeletal, and smooth muscle cells, dendritic cells, retinal pigment epithelium, and red blood cell hematopoietic precursors. $C D-36$ plays a minor role in the onset of primary tumors. CD- 36 is a glycoprotein that functions as a transporter of long-chain fatty acids and ox$L D L$, and is involved in angiogenesis, immune responses, adhesion, and metastasis. This protein is expressed in stromal, immune, and cancer cells. Different patterns of expression have been observed from the onset to the spread of cancer in different malignancies. Today, this protein is considered one of the biomarkers and therapeutic targets of cancer. The expression is also generally reduced in tumor microvessels supporting tumor progression and invasion. In Tumor Stromal cells, $C D-36$ expression is extremely low. The lower the $C D-36$ level in Cancer-Associated Fibroblasts (CAFs) is, the more aggressive the tumor is [15-18].

In recent years, it has been indicated that fat metabolism has been involved in processes related to cell transformation and tumorigenesis $[19,20]$. The results of various studies showed that serum levels of oxLDL and hs-CRP increased the risk of cancers [21-24]. The relationship between $L O X-1$ ligands and $C D-$ 36 and $L O X-1$ expression in patients with $H$. pylori infection is unclear. In this study, we investigated the relationship between serum CRP and ox-LDL levels and $C D-36$ and $L O X-1$ gene expression.

\section{Materials And Methods}

\section{Subjects}

In this cross-sectional study, we investigated 74 outpatients referred to the endoscopy department based on gastritis status in gastric biopsy and $\mathrm{H}$. pylori infection in three groups: 1- H. pylori/gastritis positive 2H. pylori-negative / gastritis positive $3 \mathrm{H}$. pylori-negative/gastritis negative. Gastritis was determined by a pathologist based on the Sydney criterion. Gastric tissue biopsy and serum specimens were used for molecular and biochemical experiments. People who, at the time of the study, had cancer, diabetes, infectious diseases, cardiovascular disease, high blood pressure and hyperlipidemia, pregnancy, anemia, kidney disease, autoimmune and inflammatory diseases, and gastrointestinal disorders, and thyroid problems, were omitted. Likewise, smokers and alcoholics and people taking anti-inflammatory, steroids, antacids, proton pump inhibitors, bismuth, and antibiotics drugs were excluded from the study.

\section{Sampling}

Blood samples were taken from the participants, and after centrifugation, its serum was isolated and kept at $-70^{\circ} \mathrm{C}$ until we conducted experiments. Gastric antrum biopsy specimens were immediately stored in $10 \%$ formalin. After fixation, the samples were molded, cut, and stained by hematoxylin and eosin (H\&E). 
We used the rest of the tissue samples for RNA extraction and gene expression analysis. To detect $H$. pylori in the gastric mucosa, we used a urease test and direct observation of bacteria in stained tissue sections.

\section{Rna Extraction And Real-time Rt-pcr}

Total RNA was extracted from antrum biopsies according to the method of the kit manufacturer (Gene All). For cDNA synthesis, according to the instructions of the cDNA synthesis kit (YTA.Co), in the initial stage, $2 \mu \mathrm{g}$ of the total RNA with $2 \mu \mathrm{l}$ of primer (each of the oligo (dT) and random hexamer $1 \mu \mathrm{l}$ ) and volume was raised to $13.4 \mu \mathrm{l}$ by DEPC-H20. It was located at $70^{\circ} \mathrm{C}$ for 5 minutes. In the second step, $4 \mu \mathrm{l}$ of buffer (5X), $1 \mu \mathrm{l}$ of dNTPs, $0.5 \mu$ l of RNase Inhibitor, and $1 \mu \mathrm{l}$ of M-MLV enzyme were added and incubated at $37^{\circ} \mathrm{C}$ for $60 \mathrm{~min}$ and then at $70^{\circ} \mathrm{C}$ for $5 \mathrm{~min}$. AllelID 7.5 software was used to design the primers (Table 1). For the real-time RT-PCR, $10 \mu \mathrm{l}$ of 2x SYBR Green (YTA Cat No: YT2551) was mixed with $0.4 \mu \mathrm{l}$ of each forward and reverse primer, and $1.5 \mu \mathrm{l}$ of cDNA with $1 \mu \mathrm{l}$ of passive reference dye (50X) and DEPC H2O. The volume was brought to $20 \mu \mathrm{l}$ and placed in a thermocycler. After an initial denaturation phase at $95^{\circ} \mathrm{C}$ for 3 minutes, the denaturation phase at $95^{\circ} \mathrm{C}$ for 5 seconds, and then the annealing/extension phase at $60^{\circ} \mathrm{C}$ for 20 seconds were performed in 40 cycles. BACT gene was an internal control, and after obtaining CT of each sample for genes, the mean was taken from CT. Afterward, the results were analyzed using the $\Delta$ CT method.

\section{ELISA}

Measurements of hs-CRP and ox-LDL were performed according to the manufacturer's kit instructions (Zell Bio).

\section{Statistical analysis}

SPSS 24 and GraphPad software programs were used for data analysis and graphs drawing, respectively. Shapiro-Wilk test was used to check the normality of the data. To compare data to normal distribution, a one-way ANOVA parametric test, and then the Tukey test was used to examine the differences between groups. Data with abnormal distributed nonparametric Kruskal-Wallis tests, and then groups were compared to the pairwise comparisons of the group test. Spearman (nonparametric) correlation was used to investigate the correlation between serum analyte concentration and gene expression. The value of $P \leq 0.05$ was considered a significant level in this study.

\section{Results}

Of the 74 participants in the study, 43 were female, and 31 were male. Pathological findings and the RUT test revealed gastritis and $H$. pylori infection in the groups (Table 2). The results indicated that 40 of these patients were $H$. pylori-negative, and 34 were $H$. pylori-positive. In addition, 11 patients had not gastritis, and 63 patients had gastritis. Comparison of BMI between the groups by the one-way ANOVA test 
showed no significant difference in the participants' BMI $(P=0.496)$. Comparison of sex and age variables in the groups using the Chi-Square test showed no significant difference between age and sex traits $(P=0.835)$.

\section{LOX-1 and CD-36 gene expression}

According to the statistical analysis of $L O X-1$ expression data using the Shapiro-Wilk test $(P \leq 0.05)$, the data distribution was not normal. Comparison of the gene expression in the three groups using the Kruskal-Wallis test showed a significant difference $(p=0.033)$. Comparison of the results between the groups using the pairwise comparisons of the group test demonstrated a significant difference between H. pylori/gastritis positive and H. pylori /gastritis negative $(p=0.025)$ and between $H$. pylori-negative / gastritis positive and $H$. pylori/gastritis negative groups $(P=0.010)$. However, no significant difference was observed between $H$. pylori/gastritis positive and $H$. pylori-negative/gastritis positive $(p=0.597)$ groups (Fig. 1).

Comparison of $C D-36$ expression using the Independent Samples Median Test showed a significant difference between the groups $(p=0.013)$. The comparison between the groups using the pairwise comparisons of the group test showed a significant difference between $H$. pylori/gastritis positive and $H$. pylori/gastritis negative $(\mathrm{p}=0.046)$. There was no significant difference between $\mathrm{H}$. pylori-negative / gastritis positive and $H$. pylori / gastritis negative $(\mathrm{p}=0.288)$, and between $H$. pylori / gastritis positive and H. pylori-negative / gastritis positive $(\mathrm{p}=0.712)$ (Fig. 2$)$.

\section{Hs-crp And Ox-Idl Results}

Comparison of the results of the hs-CRP concentration measurement in the three groups performed using the Kruskal-Wallis test showed a significant difference in the hs-CRP variable $(p<0.001)$. The groups were compared by the pairwise comparisons of the group between $H$. pylori/gastritis positive and $H$. pylori/gastritis negative $(p=0.013)$, and between $H$. pylori-negative / gastritis positive and $H$. pylori/gastritis negative $(p<.001)$. There was a significant difference between $H$. pylori/gastritis positive and $H$. pylori-negative / gastritis positive groups $(p=0.016)$.

Analysis of the ox-LDL concentration between the groups by the pairwise comparisons of the group test showed a significant difference between $H$. pylori-negative / gastritis positive and $H$. pylori and gastritis negative groups $(p=0.032)$. Furthermore, no significant difference was observed between $H$. pylori/gastritis positive and H. pylori/gastritis negative groups $(\mathrm{p}=0.440)$, and between $H$. pylori / gastritis positive and H. pylori-negative / gastritis positive $(\mathrm{p}=0.051)$.

\section{Correlation between LOX-1, CD-36 expression level, and serum hs-CRP and ox-LDL concentration}

Due to the abnormality of the data, the Spearman test was used to measure the relationship. There was a weak correlation between serum hs-CRP concentration and $L O X-1$ expression $(r=0.219, P=0.058)$. 
Owing to the abnormality of the data, the Spearman test was used to measure the relationship between them. There was no correlation between serum ox-LDL concentration and $L O X-1$ and $C D-36$ expression.

Table 1

The primer sequences

\begin{tabular}{|lll|}
\hline Gene & Primers $^{*}\left(\mathbf{5}^{\prime} \rightarrow \mathbf{3}^{\prime}\right)$ & Product size (base pair) \\
\hline LOX-1 & TAGAAACCCTTGCTCGGAAGC & 136 \\
& TGCCAGATCCAGTCTTGCG & \\
\hline CD-36 & CTTGGATATTGAACCTATAACTGGA TGTTTGCCTTCTCATCACC & 176 \\
\hline ACTB & GCCTTTGCCGATCCGC & 90 \\
& GCCGTAGCCGTTGTCG & \\
\hline * Upper sequences are forward primers.
\end{tabular}

Table 2

Demographic and clinical information of participants and groups.

\begin{tabular}{|llllll|}
\hline Groups & $\begin{array}{l}\text { Number } \\
(\text { man) }\end{array}$ & $\begin{array}{l}\text { BMI } \\
\text { Mean } \\
\mathbf{\pm S D}\end{array}$ & $\begin{array}{l}\text { Age } \\
\text { Mean } \pm \text { SD }\end{array}$ & $\begin{array}{l}\text { ox-LDL } \\
(\mathrm{ng} / \mathrm{L}) \\
\text { mean } \pm S E M\end{array}$ & $\begin{array}{l}\text { hs-CRP }(\mathrm{ng} / \mathrm{ml}) \\
\text { mean } \pm S E M\end{array}$ \\
\hline $\begin{array}{l}\text { H. pylori+ Gastritis } \\
\mathbf{+}\end{array}$ & $34(13)$ & $25.83 \pm 4.6$ & $39.88 \pm 11.6$ & 503.9 & 2044 \\
\hline H. pylori- Gastritis + & $29(14)$ & $26.33 \pm 3.8$ & $48.21 \pm 11.4$ & 698.7 & 3364 \\
\hline H. pylori- Gastritis - & $11(4)$ & $24.83 \pm 2.6$ & $39.82 \pm 11.5$ & 482.1 & 676.4 \\
\hline
\end{tabular}

\section{Discussion}

In this study, the expression levels of $L O X-1$ and $C D-36$ genes, and serum levels of hs-CRP and ox-LDL in our target groups were compared based on gastritis and $H$. pylori. The serum levels of hs-CRP and ox-LDL were higher in $H$. pylori-positive patients. Our results indicated that $H$. pylori increased LOX-1 and decreased $C D$-36 gene expression. Moreover, a weak correlation was observed between the serum level of CRP and the expression of $L O X-1$, while there was no correlation between the serum level of ox-LDL and the expression of genes. In summary, our results demonstrated that there were higher serum levels of CRP and ox-LDL and expression of the LOX-1 gene in the group with negative $H$. pylori-gastritis positive than in the control group. Although in the H. pylori and gastritis-positive group, the serum level of CRP and LOX1expression was higher, the expression of $C D-36$ decreased despite the high level of ox-LDL (Fig. 5).

In this work, the effects of smoking, alcohol consumption, use of any drugs, use of antacids, use of antiinflammatory medications, antibiotics, anti- $\mathrm{H}$. Pylori drugs were excluded according to the inclusion and exclusion criteria. It furthermore balanced the body mass index in the three groups. In addition, none of 
the people in their first-degree relatives had a history of gastric cancer. Therefore, the effects seen were due to infection with this bacterium and gastritis.

The role of $H$. pylori, inflammation and hyperlipidemia in the evolution of distal gastric adenocarcinoma has been demonstrated [25-27]; however, its molecular mechanism is unclear. According to the results of the study conducted by Huang et al., plasma levels of hs-CRP and ox-LDL were higher in atherosclerotic $\mathrm{CHD}$ patients with $\mathrm{Cag}^{+} H$. pylori infection [28]. Studies by Jafarzadeh et al. showed that although serum hs-CRP levels increased in $H$. pylori infection, this increase in hs-CRP was not affected by the bacterial CagA status [10]. In our study, it appears in the H. pyloril gastritis positive group, H. pylori were the leading cause of the increase in serum hs-CRP levels.

Studies show that in gastric cancer, ox-LDL interaction with the LOX-1 receptor causes NF-KB pathway activation and increases vascular endothelial growth factor C (VEGF-c) expression [26]. Furthermore, the use of ox-LDL binding inhibitor inhibits VEGEF-c expression. Pascual et al. in their study found that $C D$ $36^{+}$metastasis initiating cells in highly invasive melanoma, lung carcinoma, bladder, and breast cancer patients were associated with a poor prognosis. Moreover, Inhibition of $C D-36$ in animal models of breast cancer and melanoma prevented metastasis [17].

In study conducted by the Kashihara et al. Investigating noncancerous gastric tissue obtained from 39 gastrectomy patients, the level of glycoprotein thrombospondin 1 (TSP-1), which is a CD-36 ligand, was measured, and patients in both groups with high and low TSP-1 were compared. Noncancerous gastric tissue of patients with high TSP-1 levels had higher carcinogenesis and more active $C D-36$ signaling. Although in these studies several patients had H. pylori infection, the effect of H. pylori on $C D-36$ gene expression was not investigated [29].

Some studies have investigated the effect of palmitic acid fatty acids as $C D-36$ ligand on signal transduction pathways in gastric cancer metastasis [30,15]. Accordingly, $C D-36$ levels show a significant upregulation in malignant tissue. In these studies, they introduced $C D-36$ as an oncogenic factor involved in cancer progression. However, another study reported downregulation of $C D-36$ in Cancer-Associated Fibroblasts (CAFs), in more aggressive tumors [18]. Although low levels of $C D-36$ are associated with low TNM (tumor, node, metastasis) classification in pancreatic ductal adenocarcinoma (PDAC) cancer, they are associated with a larger tumor size and a weaker disease prognosis [31].

Analysis of the mRNA extracted from gastric tissue samples of 10 patients with $H$. pylori showed that out of 13817 transcripts, 98 transcripts increased after $H$. pylori treatment and bacterial eradication $(P<0.02$ fold change threshold) [32]. $C D-36$ was one gene whose expression increased significantly (approximately 2.95 times). In agreement with the investigation conducted by Resnick et al., the expression analysis in our study exhibited a decrease in $C D-36$ expression in the $H$. pylori group.

According to the results, the primary reason for high LOX-1 expression in the $\mathrm{H}$. pylori group is the activation of the inflammatory pathway. It appears that CRP acts as the dominant ligand for the LOX-1 receptor. There is evidence that CRP is suggested as a ligand for LOX-1 and induced genes involved in 
tumorigenesis $[33,34]$. In addition to the ligands for $L O X-1$ and $C D-36$, direct bacterial interaction with these receptors may have caused the molecular changes observed in gastric cells. Kattoor et al. in their study revealed that infectious agents, such as Chlamydia pneumoniae and $H$. pylori, could increase their expression by direct interaction with the LOX-1 receptor [35]. In this study, they showed that Chlamydia pneumoniae bound to LOX-1 in human umbilical vein endothelial cells (HUVECs) and allowed ox-LDL to enter the cells. They also observed this mechanism in the lung and adductor tissues of mice. However, this study showed that Chlamydia pneumoniae was only useful on LOX-1 and had no effect on the expression and signaling of the $C D-36$ gene [36]. One limitation of this study was the small amount of biopsy and serum samples of patients; therefore, molecular studies at the protein level were impossible to conduct.

\section{Conclusion}

Based on the investigation results, two factors, $H$. pylori, and gastritis, increase $L O X-1$ expression and decrease $C D-36$ expression. The increase in plasma hs-CRP levels may be associated with an increase in LOX-1 expression. In future studies, the effect of $H$. pylori and gastric cells coculture on the expression of LOX-1 and $C D-36$ genes and the impact of bacteria on the internalization of ox-LDL should be investigated.

\section{Declarations}

\section{Acknowledgment}

The research presented in this article is part of the dissertation of Gholamreza ghanbariha to receive a master's degree in clinical biochemistry. The Semnan University of Medical Sciences sponsored this project under project no. 1464. We want to thank the Kosar hospital research deputy and Clinical Research Development Unit of the Semnan University of Medical Sciences for cooperation and providing facilities for the work.

\section{The author contribution}

AP: Concept generation, Study Design, Project supervision, Manuscript Preparation. GG: Data Collection, Experimentation. Literature Search. MH: Data Collection. RD: Data Collection. : MMK: Statistical Analysis, Data Interpretation.

\section{Compliance with ethical standards}

Conflict of interest The authors declare no conflict of interests

Ethical approval All procedures performed in this study were approved in the Ethics Committee of Semnan University of Medical Sciences with the ethics code IR.SEMUMS.REC.1397.146.

Informed consent Informed consent was obtained from all individual participants included in the study. 


\section{References}

1. Reshetnyak VI, Burmistrov Al, Maev IV (2021) Helicobacter pylori: Commensal, symbiont or pathogen? World J Gastroenterol 27(7):545-560. doi:10.3748/wjg.v27.i7.545

2. Cai Q, Shi P, Yuan Y, Peng J, Ou X, Zhou W, Li J, Su T, Lin L, Cai S, He Y, Xu J (2021) InflammationAssociated Senescence Promotes Helicobacter pylori-Induced Atrophic Gastritis. Cell Mol Gastroenterol Hepatol 11(3):857-880. doi:10.1016/j.jcmgh.2020.10.015

3. Rizzacasa B, Morini E, Pucci S, Murdocca M, Novelli G, Amati F (2017) LOX-1 and Its Splice Variants: A New Challenge for Atherosclerosis and Cancer-Targeted Therapies. Int J Mol Sci 18(2). doi:10.3390/ijms18020290

4. Nakashima-Nakasuga C, Hazama S, Suzuki N, Nakagami Y, Xu M, Yoshida S, Tomochika S, Fujiwara N, Matsukuma S, Matsui H, Tokumitsu Y, Kanekiyo S, Shindo Y, Maeda N, Tsunedomi R, lida M, Takeda S, Yoshino S, Ueno T, Hamamoto Y, Ogihara H, Hoshii Y, Nagano H (2020) Serum LOX-1 is a novel prognostic biomarker of colorectal cancer. Int J Clin Oncol 25(7):1308-1317. doi:10.1007/s10147-020-01673-2

5. Pucci S, Polidoro C, Greggi C, Amati F, Morini E, Murdocca M, Biancolella M, Orlandi A, Sangiuolo F, Novelli G (2019) Pro-oncogenic action of LOX-1 and its splice variant LOX-1Delta4 in breast cancer phenotypes. Cell Death Dis 10(2):53. doi:10.1038/s41419-018-1279-1

6. Zhang J, Zhang L, Li C, Yang C, Li L, Song S, Wu H, Liu F, Wang L, Gu J (2018) LOX-1 is a poor prognostic indicator and induces epithelial-mesenchymal transition and metastasis in pancreatic cancer patients. Cell Oncol (Dordr) 41(1):73-84. doi:10.1007/s13402-017-0360-6

7. Liang M, Zhang P, Fu J (2007) Up-regulation of LOX-1 expression by TNF-alpha promotes transendothelial migration of MDA-MB-231 breast cancer cells. Cancer Lett 258(1):31-37. doi:10.1016/j.canlet.2007.08.003

8. Shih HH, Zhang S, Cao W, Hahn A, Wang J, Paulsen JE, Harnish DC (2009) CRP is a novel ligand for the oxidized LDL receptor LOX-1. Am J Physiol Heart Circ Physiol 296(5):H1643-1650. doi:10.1152/ajpheart.00938.2008

9. Madrigal-Ruíz PM, Navarro-Hernández RE, Ruíz-Quezada SL, Corona-Meraz Fl, Vázquez-Del Mercado M, Gómez-Bañuelos E, Castro-Albarran J, Sandoval-García F, Flores-Alvarado LJ, Martín-Marquez BT (2016) Low CD36 and LOX-1 Levels and CD36 Gene Subexpression Are Associated with Metabolic Dysregulation in Older Individuals with Abdominal Obesity. J Diabetes Res 2016:5678946. doi:10.1155/2016/5678946

10. Jafarzadeh A, Hassanshahi GH, Nemati M (2009) Serum Levels of High-Sensitivity C-Reactive Protein (hs-CRP) in Helicobacter pylori-Infected Peptic Ulcer Patients and Its Association with Bacterial CagA Virulence Factor. Dig Dis Sci 54(12):2612. doi:10.1007/s10620-008-0686-z

11. Yu Q, Yu XF, Zhang SD, Wang HH, Wang HY, Teng LS (2013) Prognostic role of C-reactive protein in gastric cancer: a meta-analysis. Asian Pac J Cancer Prev 14(10):5735-5740. doi:10.7314/apjcp.2013.14.10.5735 
12. Murdocca M, Capuano R, Pucci S, Cicconi R, Polidoro C, Catini A, Martinelli E, Paolesse R, Orlandi A, Mango R, Novelli G, Di Natale C, Sangiuolo F (2019) Targeting LOX-1 Inhibits Colorectal Cancer Metastasis in an Animal Model. Front Oncol 9:927. doi:10.3389/fonc.2019.00927

13. Li C, Zhang J, Wu H, Li L, Yang C, Song S, Peng P, Shao M, Zhang M, Zhao J, Zhao R, Wu W, Ruan Y, Wang L, Gu J (2017) Lectin-like oxidized low-density lipoprotein receptor-1 facilitates metastasis of gastric cancer through driving epithelial-mesenchymal transition and PI3K/Akt/GSK3beta activation. Sci Rep 7:45275. doi:10.1038/srep45275

14. Gonzalez-Chavarria I, Fernandez E, Gutierrez N, Gonzalez-Horta EE, Sandoval F, Cifuentes P, Castillo C, Cerro R, Sanchez O, Toledo JR (2018) LOX-1 activation by oxLDL triggers an epithelial mesenchymal transition and promotes tumorigenic potential in prostate cancer cells. Cancer Lett 414:34-43. doi:10.1016/j.canlet.2017.10.035

15. Pan J, Fan Z, Wang Z, Dai Q, Xiang Z, Yuan F, Yan M, Zhu Z, Liu B, Li C (2019) CD36 mediates palmitate acid-induced metastasis of gastric cancer via AKT/GSK-3beta/beta-catenin pathway. $J$ Exp Clin Cancer Res 38(1):52. doi:10.1186/s13046-019-1049-7

16. Cai L, Wang Z, Ji A, Meyer JM, van der Westhuyzen DR (2012) Scavenger receptor CD36 expression contributes to adipose tissue inflammation and cell death in diet-induced obesity. PLOS ONE 7(5):e36785. doi:10.1371/journal.pone.0036785

17. Pascual G, Avgustinova A, Mejetta S, Martín M, Castellanos A, Attolini CS-O, Berenguer A, Prats N, Toll A, Hueto JA, Bescós C, Di Croce L, Benitah SA (2017) Targeting metastasis-initiating cells through the fatty acid receptor CD36. Nature 541(7635):41-45. doi:10.1038/nature20791

18. Tanase C, Gheorghisan-Galateanu A-A, Popescu ID, Mihai S, Codrici E, Albulescu R, Hinescu ME (2020) CD36 and CD97 in Pancreatic Cancer versus Other Malignancies. Int J Mol Sci 21(16):5656. doi:10.3390/ijms21165656

19. Zhang D, Xi Y, Feng Y (2021) Ovarian cancer risk in relation to blood lipid levels and hyperlipidemia: a systematic review and meta-analysis of observational epidemiologic studies. Eur $\mathrm{J}$ Cancer Prev 30(2):161-170. doi:10.1097/CEJ.0000000000000597

20. Shen Y, Wang C, Ren Y, Ye J (2018) A comprehensive look at the role of hyperlipidemia in promoting colorectal cancer liver metastasis. J Cancer 9(16):2981-2986. doi:10.7150/jca.25640

21. Bitorina AV, Oligschlaeger Y, Shiri-Sverdlov R, Theys J (2019) Low profile high value target: The role of OxLDL in cancer. Biochim Biophys Acta Mol Cell Biol Lipids 1864(12):158518. doi:10.1016/j.bbalip.2019.158518

22. Siyin ST, Liu T, Li W, Yao N, Xu G, Qu J, Chen Y (2020) A prospective follow-up study of the relationship between high-sensitivity C-reactive protein and primary liver cancer. BMC Cancer 20(1):1168. doi:10.1186/s12885-020-07665-9

23. Muller DC, Larose TL, Hodge A, Guida F, Langhammer A, Grankvist K, Meyer K, Cai Q, Arslan AA, Zeleniuch-Jacquotte A, Albanes D, Giles GG, Sesso HD, Lee IM, Gaziano JM, Yuan JM, Hoffman Bolton J, Buring JE, Visvanathan K, Le Marchand L, Purdue MP, Caporaso NE, Midttun O, Ueland PM, Prentice RL, Weinstein SJ, Stevens VL, Zheng W, Blot WJ, Shu XO, Zhang X, Xiang YB, Koh WP, Hveem 
K, Thomson CA, Pettinger M, Engstrom G, Brunnstrom H, Milne RL, Stampfer MJ, Han J, Johansson M, Brennan P, Severi G, Johansson M (2019) Circulating high sensitivity $C$ reactive protein concentrations and risk of lung cancer: nested case-control study within Lung Cancer Cohort Consortium. BMJ 364:k4981. doi:10.1136/bmj.k4981

24. Casadei Gardini A, Carloni S, Scarpi E, Maltoni P, Dorizzi RM, Passardi A, Frassineti GL, Cortesi P, Giannini MB, Marisi G, Amadori D, Lucchesi A (2016) Prognostic role of serum concentrations of high-sensitivity $\mathrm{C}$-reactive protein in patients with metastatic colorectal cancer: results from the ITACa trial. Oncotarget 7(9):10193-10202. doi:10.18632/oncotarget.7166

25. Varga MG, Wood CR, Butt J, Ryan ME, You WC, Pan K, Waterboer T, Epplein M, Shaffer CL (2021) Immunostimulatory membrane proteins potentiate $\mathrm{H}$. pylori-induced carcinogenesis by enabling CagA translocation. Gut Microbes 13(1):1-13. doi:10.1080/19490976.2020.1862613

26. Ma C, Xie J, Luo C, Yin H, Li R, Wang X, Xiong W, Zhang T, Jiang P, Qi W, Zhou T, Yang Z, Wang W, Ma $J$, Gao G, Yang X (2019) OxLDL promotes lymphangiogenesis and lymphatic metastasis in gastric cancer by upregulating VEGFC expression and secretion. Int J Oncol 54(2):572-584. doi:10.3892/ijo.2018.4648

27. Lu J, Xu BB, Xue Z, Xie JW, Zheng CH, Huang CM, Li P (2021) Perioperative CRP: A novel inflammation-based classification in gastric cancer for recurrence and chemotherapy benefit. Cancer Med 10(1):34-44. doi:10.1002/cam4.3514

28. Huang B, Chen Y, Xie Q, Lin G, Wu Y, Feng Y, Li J, Zhuo Y, Zhang P (2011) CagA-positive Helicobacter pylori strains enhanced coronary atherosclerosis by increasing serum OxLDL and HsCRP in patients with coronary heart disease. Dig Dis Sci 56(1):109-114. doi:10.1007/s10620-010-1274-6

29. Kashihara H, Shimada M, Yoshikawa K, Higashijima J, Tokunaga T, Nishi M, Takasu C, Ishikawa D (2017) Correlation Between Thrombospondin-1 Expression in Non-cancer Tissue and Gastric Carcinogenesis. Anticancer Res 37(7):3547-3552. doi:10.21873/anticanres.11724

30. Jiang M, Wu N, Xu B, Chu Y, Li X, Su S, Chen D, Li W, Shi Y, Gao X, Zhang H, Zhang Z, Du W, Nie Y, Liang J, Fan D (2019) Fatty acid-induced CD36 expression via O-GIcNAcylation drives gastric cancer metastasis. Theranostics 9(18):5359-5373. doi:10.7150/thno.34024

31. Jia S, Zhou L, Shen T, Zhou S, Ding G, Cao L (2018) Down-expression of CD36 in pancreatic adenocarcinoma and its correlation with clinicopathological features and prognosis. J Cancer 9(3):578-583. doi:10.7150/jca.21046

32. Resnick MB, Sabo E, Meitner PA, Kim SS, Cho Y, Kim HK, Tavares R, Moss SF (2006) Global analysis of the human gastric epithelial transcriptome altered by Helicobacter pylori eradication in vivo. Gut 55(12):1717-1724. doi:10.1136/gut.2006.095646

33. Chen Y, Cong R, Ji C, Ruan W (2020) The prognostic role of C-reactive protein in patients with head and neck squamous cell carcinoma: A meta-analysis. Cancer Med 9(24):9541-9553. doi:https://doi.org/10.1002/cam4.3520

34. Jung SY, Papp JC, Sobel EM, Pellegrini M, Yu H, Zhang Z-F (2020) Pro-inflammatory cytokine polymorphisms in ONECUT2 and HNF4A and primary colorectal carcinoma: a post genome-wide 
gene-lifestyle interaction study. Am J cancer Res 10(9):2955-2976

35. Kattoor AJ, Goel A, Mehta JL (2019) LOX-1: Regulation, Signaling and Its Role in Atherosclerosis. Antioxid (Basel) 8(7). doi:10.3390/antiox8070218

36. Campbell LA, Puolakkainen M, Lee A, Rosenfeld ME, Garrigues HJ, Kuo CC (2012) Chlamydia pneumoniae binds to the lectin-like oxidized LDL receptor for infection of endothelial cells. Microbes Infect 14(1):43-49. doi:10.1016/j.micinf.2011.08.003

\section{Figures}

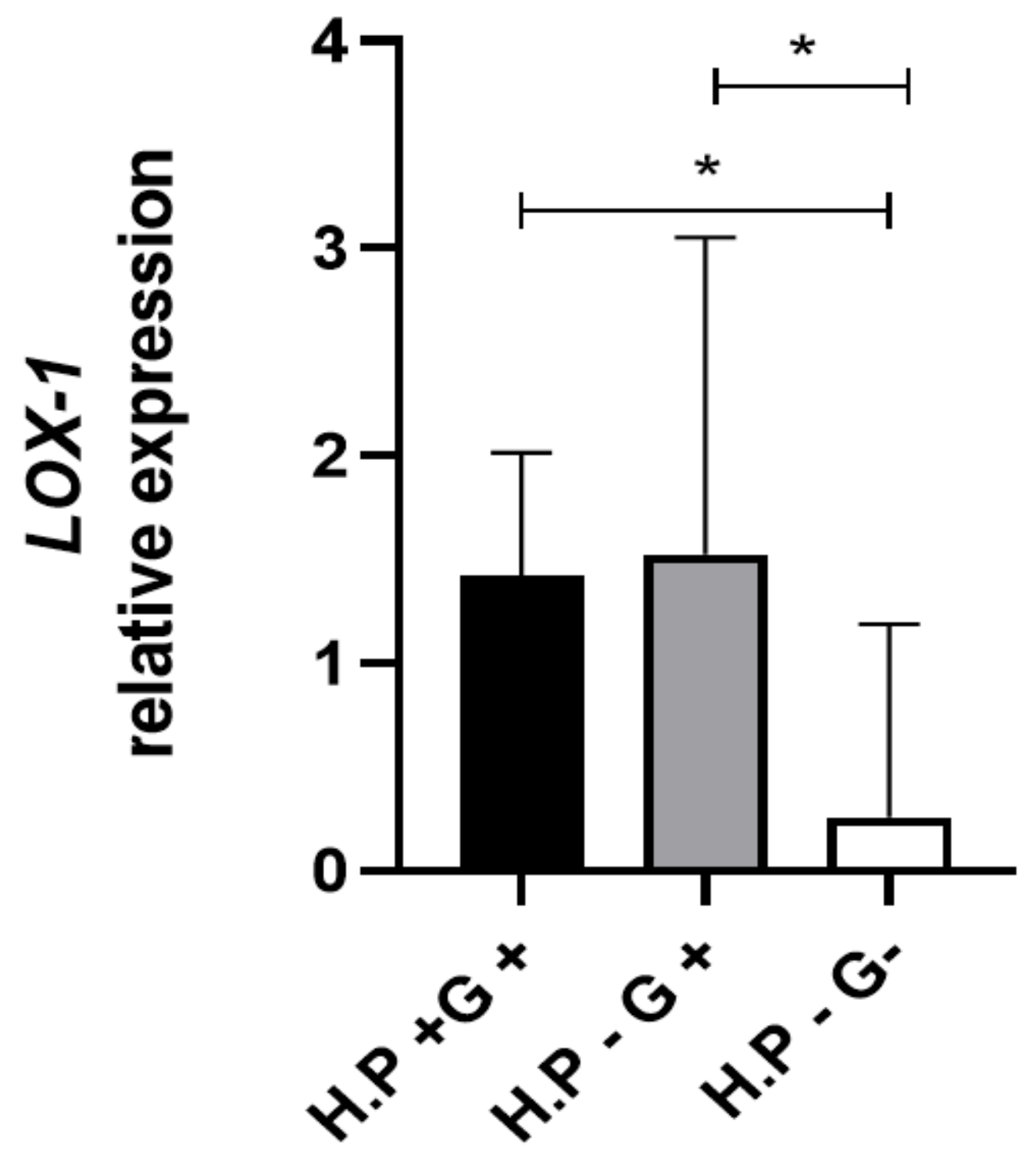

Figure 1

Comparison of $L O X-1$ relative expression levels in the three groups. Data were expressed as median (Interquartile Range). ${ }^{*} \mathrm{P}<0.05$, Kruskal-Wallis test, H.P-G-, H.P-G+, H.P+G+ are H. pylori-negative without gastritis, H. pylori-negative with gastritis, and $\mathrm{H}+\mathrm{G}+$ : H. pylori-positive with gastritis, respectively. 


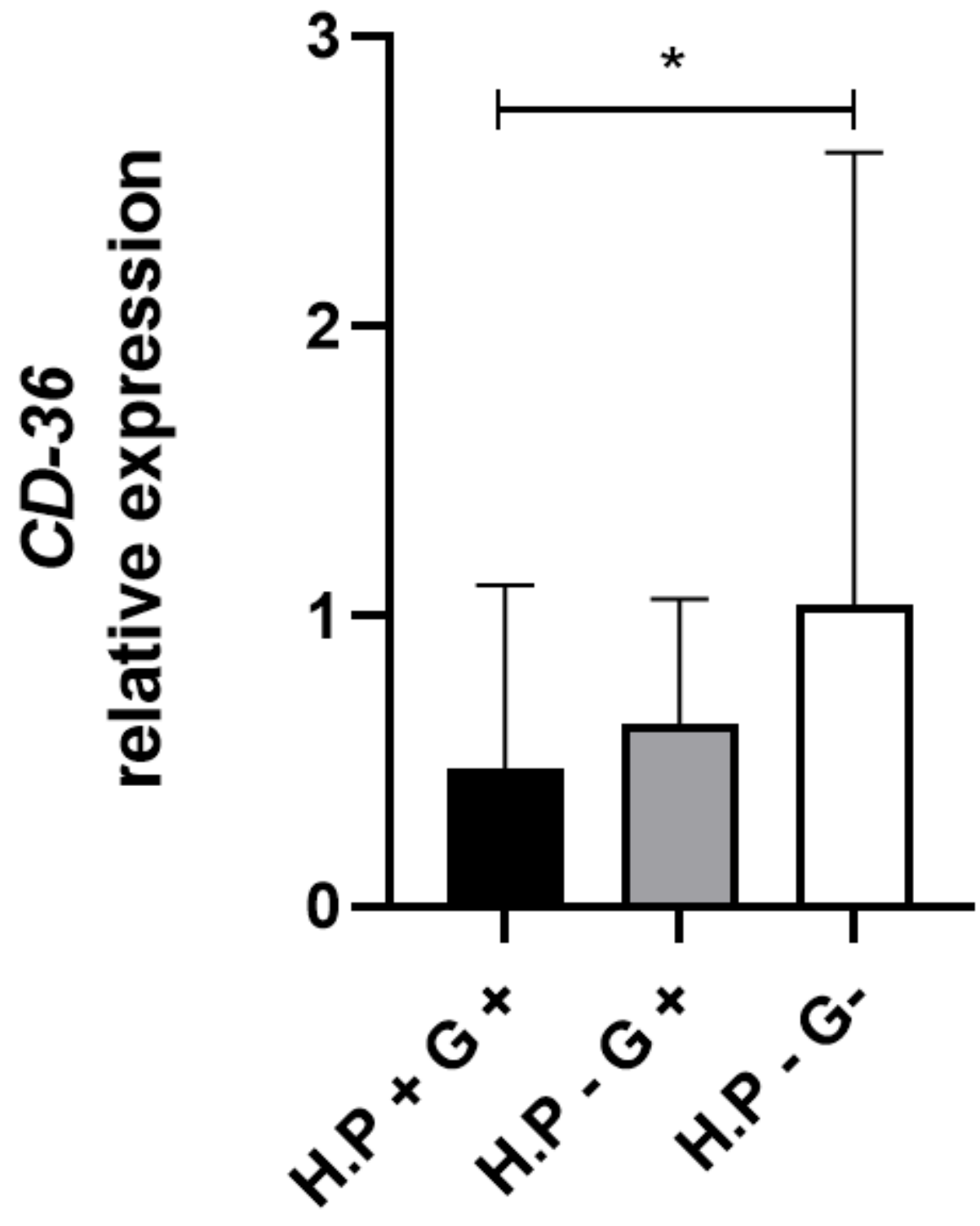

Figure 2

Comparison of $C D-36$ relative expression levels in the three groups. Data were expressed as median (Interquartile Range). ${ }^{*} \mathrm{P}<0.05$, Kruskal-Wallis test, H.P-G-, H.P-G+, H.P+G+ are H. pylori-negative without gastritis, H. pylori-negative with gastritis, and $\mathrm{H}+\mathrm{G}+$ : H. pylori-positive with gastritis, respectively. 


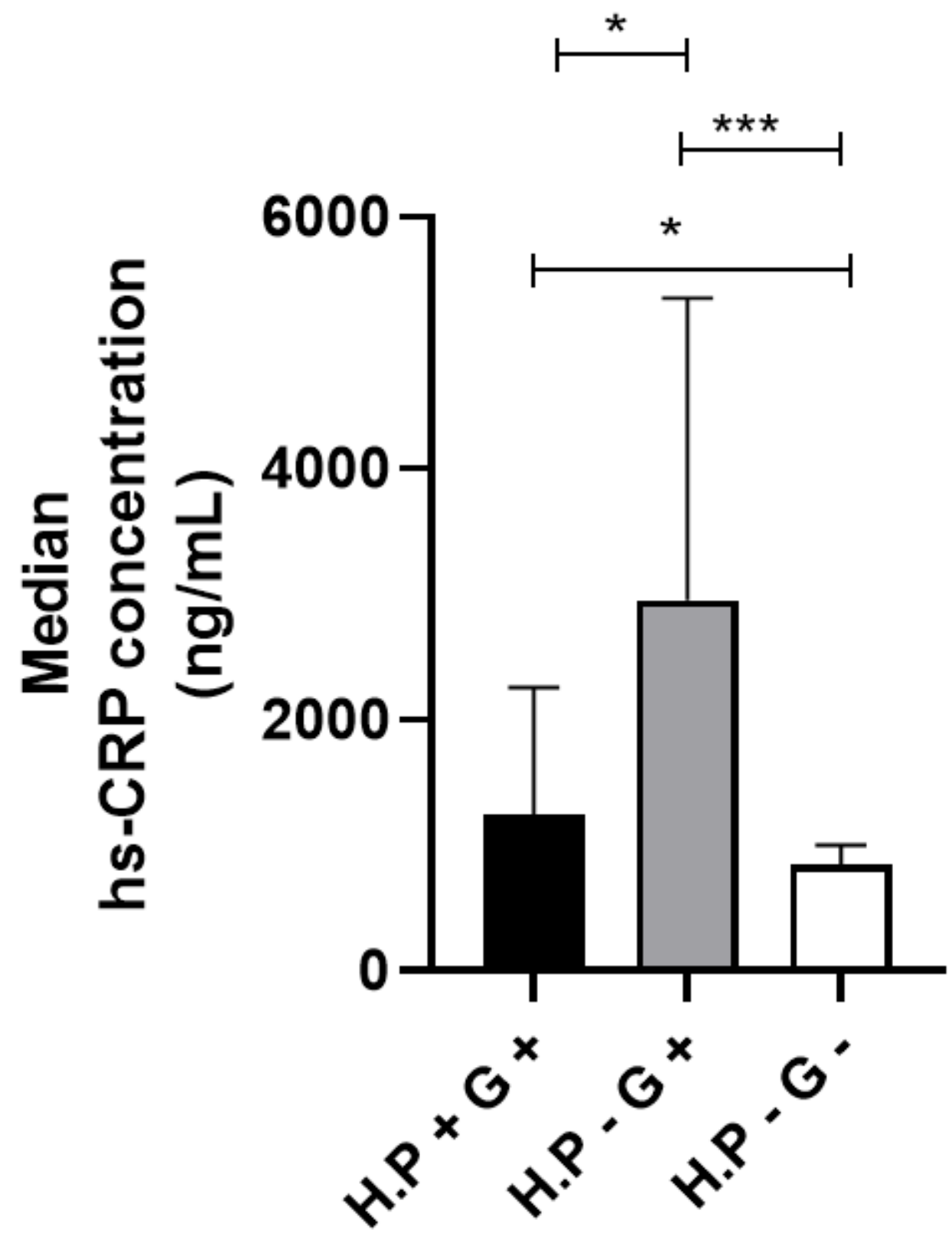

Figure 3

Comparison of hs-CRP levels in the three groups. Data were expressed as median (Interquartile Range). ${ }^{*} \mathrm{P}<0.05,{ }^{* \star} \mathrm{P}<0.001$, Kruskal-Wallis test, H.P-G-, H.P-G+, H.P+G+ are H. pylori-negative without gastritis, H. pylori-negative with gastritis, and $\mathrm{H}+\mathrm{G}+$ : H. pylori-positive with gastritis, respectively. 


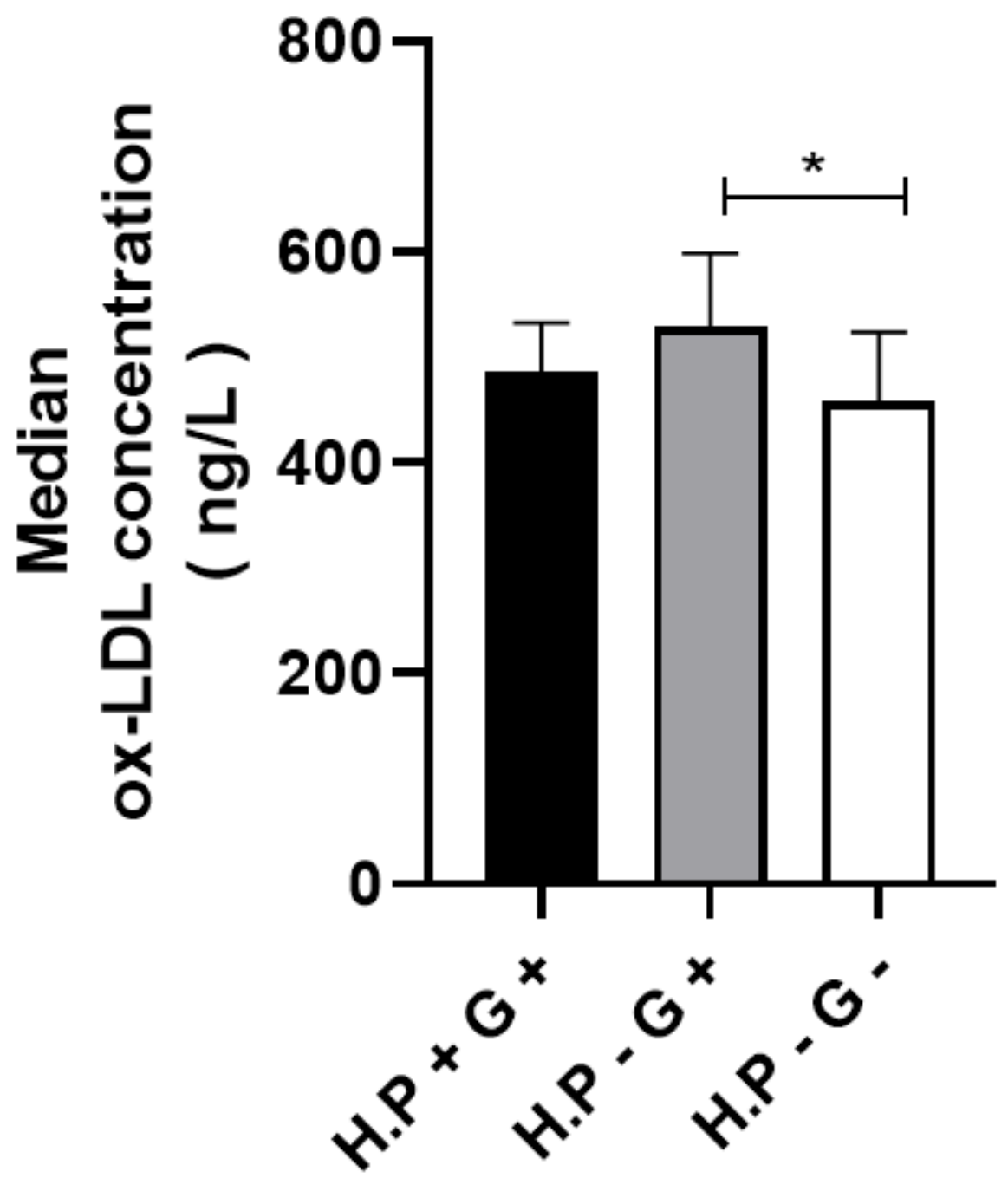

Figure 4

Comparison of ox-LDL levels in the three groups. Data were expressed as median (Interquartile Range). ${ }^{\star} \mathrm{P}<0.05,{ }^{\star \star \star} \mathrm{P}<0.001$, Kruskal-Wallis test, H.P-G-, H.P-G+, H.P+G+ are H. pylori-negative without gastritis, $H$. pylori-negative with gastritis, and $\mathrm{H}+\mathrm{G}+$ : H. pylori-positive with gastritis, respectively. 


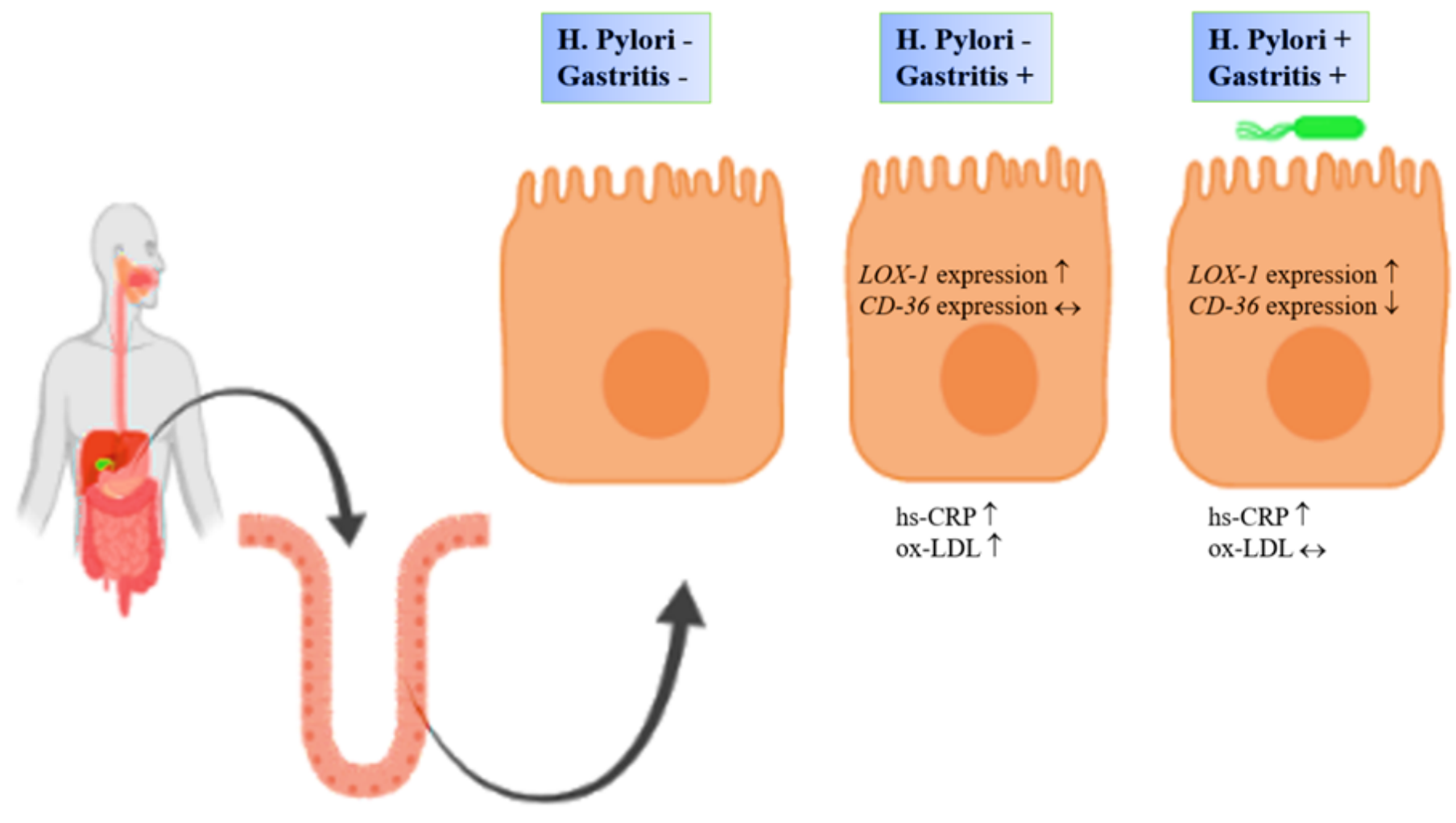

Figure 5

Gene expression status in the studied groups. Comparison of the groups was performed with H. pylori and gastritis negative. $\uparrow$ : Increase. $\downarrow$ : Decrease. $\leftrightarrow$ : Unchanged. 